\title{
症例報告
}

\section{多彩な症状を呈した中枢神経性ループス，ループス脊䯣炎に対しステロイドパルス療法および シクロホスファミドパルス療法が奏功した一例}

\author{
平野 亨*1, 萩原圭祐*1, 河合麻理*1, 桑原裕 祐*1, 山鳥大材*1 \\ 嶋 良仁 ${ }^{* 1}$, 緒方 篤*1, 田中敏 郎*1, 吉 崎 和 幸*2, 川瀬一 郎*1
}

\section{Successful therapy with steroid and cyclophosphamide pulse for CNS lupus and lupus myelitis}

\author{
Toru HiRANO*1, Keisuke HAGIHARAi ${ }^{* 1}$, Mari KAWAI ${ }^{* 1}$, Yusuke KuWAHARA ${ }^{* 1}$, Tomoki YAMAdoRI ${ }^{* 1}$, \\ Yoshihito SHIMA $^{* 1}$, Atsushi OGATA ${ }^{* 1}$, Toshio TANAKA ${ }^{* 1}$, Kazuyuki YOSHIZAKI ${ }^{* 2}$ and Ichiro KAwASE*1 \\ ${ }^{*}$ Department of Respiratory Medicine, Allergic and Rheumatic Diseases, Osaka University Graduate School of Medicine \\ ${ }^{*}$ Health center, Osaka University
}

(Received April 10, 2007)

\begin{abstract}
summary
The patient was a 33 year female. In 2001, she was diagnosed with systemic lupus erythematosus (SLE) and treated with prednisolone and ciclosporin. In May 2006, she noticed slight muscle weakness in the bilateral lower limbs. In July of the same year, she experienced gait difficulty and was admitted to our hospital because of fatigue, appetite loss, fever and disorientation. Soon afterwards, she had a fit of general convulsion and suffered from urinary retention and fecal incontinence. A brain magnetic resonance image revealed atrophy of the thoracic cord in T2 weighted images, and cerebrospinal fluid examination showed high total protein and interleukin-6 concentration, indicating complication of lupus myelitis as well as cerebral involvement. Steroid pulse and oral prednisolone treatment resulted in ameriolation of cerebral complications such as disorientation and convulsion, but muscle weakness and paresthesia in the lower limbs and urinary retention persisted. Cyclophosphamide pulse therapy was started and resulted in a marked recovery from muscle weakness, paresthesia and urinary retention, and she could discharge. We conclude that steroid and cyclophasphamide pulse therapy for a SLE patient with CNS lupus and lupus myelitisis is effective for ameriolation of symptoms such as disorientation, convulsion, urinary retension, fecal incontinence, muscle weakness and paresthesia in the lower limbs as well as elevated level of serum anti-ribosomal $\mathrm{P}$ antibody.
\end{abstract}

Key words_ CNS lupus; Lupus myelitis; Intravenous cyclophosphamide

抄録

症例は 33 歳女性，2001 年，全身性エリテマトーデスと診断され，ステロイド剤と ciclosporin の投与にて治療さ れていた． 2006 年 5 月頃より，両下肢の脱力を自覚し，徐々に自立歩行が困難となった７月より全身倦怠感，発 熱, 食欲不振, 見当識障害を認め, 入院となった. 入院後まもなく, 全身性痤攣が出現し不穏状態となった.さら に同時期より尿閉，便失禁，下肢末端の強いしびれが出現した．MRI 上，脳に異常所見はなく，胸髄の萎縮所見 が認められた。血中の抗リボソーム P 抗体の上昇と髄液の蛋白および IL-6 の増加所見をあわせ，中枢神経性ル一 プス，ループス脊髄炎と診断した。ステロイドパルス療法および経ロステロイド療法を行い，痤攣，意識障害の改 善を認めた．その後も尿閉，下肢の感覚運動障害は遷延したが， cyclophosphamideパルス療法の併用により，10 月頃より自尿の再開，下肢の脱力としびれの改善を認めた. 自立歩行が可能となり11 月退院となった。本症例 は，中枢神経性ループスによる意識障害，痤攣，膀胱直腸障害，下肢の運動，感覚障害等の多彩な症状と血中抗リ ボソーム P 抗体の高值を認め，ステロイドパルス療法および cyclophosphamide パルス療法が著効した症例である.

はじめに

中枢神経性ループスの発症において，稀に横断性

\footnotetext{
${ }^{*} 1$ 大阪大学大学院医学系研究科 呼吸器免疫アレル ギー内科学

*2大阪大学保健センター
}

脊髄炎の発症をみることがあり，障害脊髄レベルに 対応した運動障害, 感覚障害, 自律神経障害を認め る. とくに膀胱直腸障害や深部腱反射の克進, 病的 反射の出現，四肢の脱力やしびれ，感覚鈍麻を認め ることが多い1)。これらの所見に加え, 脊髄 MRI で，春髄の肥厚あるいは萎縮， T2 強調像での春髄 
内の高信号域の散在などの所見が見られる 液検査では, 細胞数増加, 蛋白増加, 炎症性サイト カインである Interleukin-6 (IL-6) や TNF- $\alpha$ 上昇 が見られる.ループス寿髄炎の治療経過に関して は，ステロイド大量内服に加え，ステロイドパルス 療法や cyclophosphamide パルス療法, 血漿交換な ぞの報告があるが，一部の症例では治療抵抗性を示 し，症状が不可逆的となりうる2 5).

今回, 脊髄障害に特徵的な症状をきたし, MRI 上は胸髄の萎縮所見のみが認められたが, 髄液蛋白 および IL-6 の上昇や血清抗りボソーム P 抗体の高 值から，中枢神経性ループスとこれによる横断性脊 髄炎と診断し，ステロイドパルス療法および cyclophosphamide パルス療法が奏功した一例を経験 したので報告する.

\section{症例}

症 例 : 33 歳, 女性

主 訴: 見当識障害, 下肢脱力感, 下肢のしび れ，尿閉

既往歴 : 特記事項なし

家族歴：特記事項なし

現病歴：1993 年, 全身倦意感, 浮腫が出現し, 近医にて膠原病と診断され，ステロイド剂を投与さ れた（詳細不明）。2001 年, 発熱, 全身倦怠感, 浮 腫，皮膚潰瘍，低補体血症，血小板低下などから全
身性エリテマトーデスと診断され, 以後 prednisolone 抢よび ciclosporin を投与されていた．たびた び下腿の皮膚潰瘍の増悪を認め, 入退院を繰り返し ていた. 2006 年 5 月頃より, 両下肢の脱力を自覚 し, 徐々に自立歩行が困難となった。 また尿意を感 じるものの尿が出にくいことを自覚していた．7月 初めより全身倦怠感, 発熱, 食欲不振, 見当識障害 を認め, 入院となった。

入院時現症: 身長 $158 \mathrm{~cm}$, 体重 $46.4 \mathrm{Kg}$, 体温 $39.7^{\circ} \mathrm{C}$, 血圧 $86 / 56 \mathrm{mmHg}$, 脈拍 $108 /$ 分 - 整, 意 識は軽度混濁し見当識障害を認める, 口腔に異常な し, 澒部に異常なし, 胸部に異常なし, 腹部は平坦 軟で圧痛なし, 両下腿前面に $5 \times 10 \mathrm{~cm}$ 大の皮膚潰 瘍を認める, 深部腱反射は両下肢において六進し両 バビンスキー反射陽性である, 両下肢筋力低下を対 称性に認める $(\mathrm{MMT}(\mathrm{rt} / \mathrm{lt}) \quad$ Iliopsoas $3+/ 3+$, Quadri. 3+/3+, Gastro. 3+/3+, Ham. 4-/4-, Tib. Ant. 4-/4-), 四肢感覚障害は明らかではな い, 脳神経系に明らかな異常所見なし

入院時検査所見（表 1)：入院時, 尿中白血球多 数, 細菌多数, CRP 陽性と尿路感染所見があり, 感染による白血球増多と脱水による血液濃縮所見を 認めた。生化学検查では肝腎機能, 電解質, 糖脂質 代謝に異常はなかった. 免疫学的検查においては C3 $46 \mathrm{mg} / \mathrm{dl}, \mathrm{C} 411 \mathrm{mg} / \mathrm{dl}$, 血清補体価 $22.8 \mathrm{U} / \mathrm{ml}$ と 低下, 抗 ds-DNA 抗体 $65.5 \mathrm{IU} / \mathrm{ml}$ と上昇, 抗リン

表 1 入院時検査所見

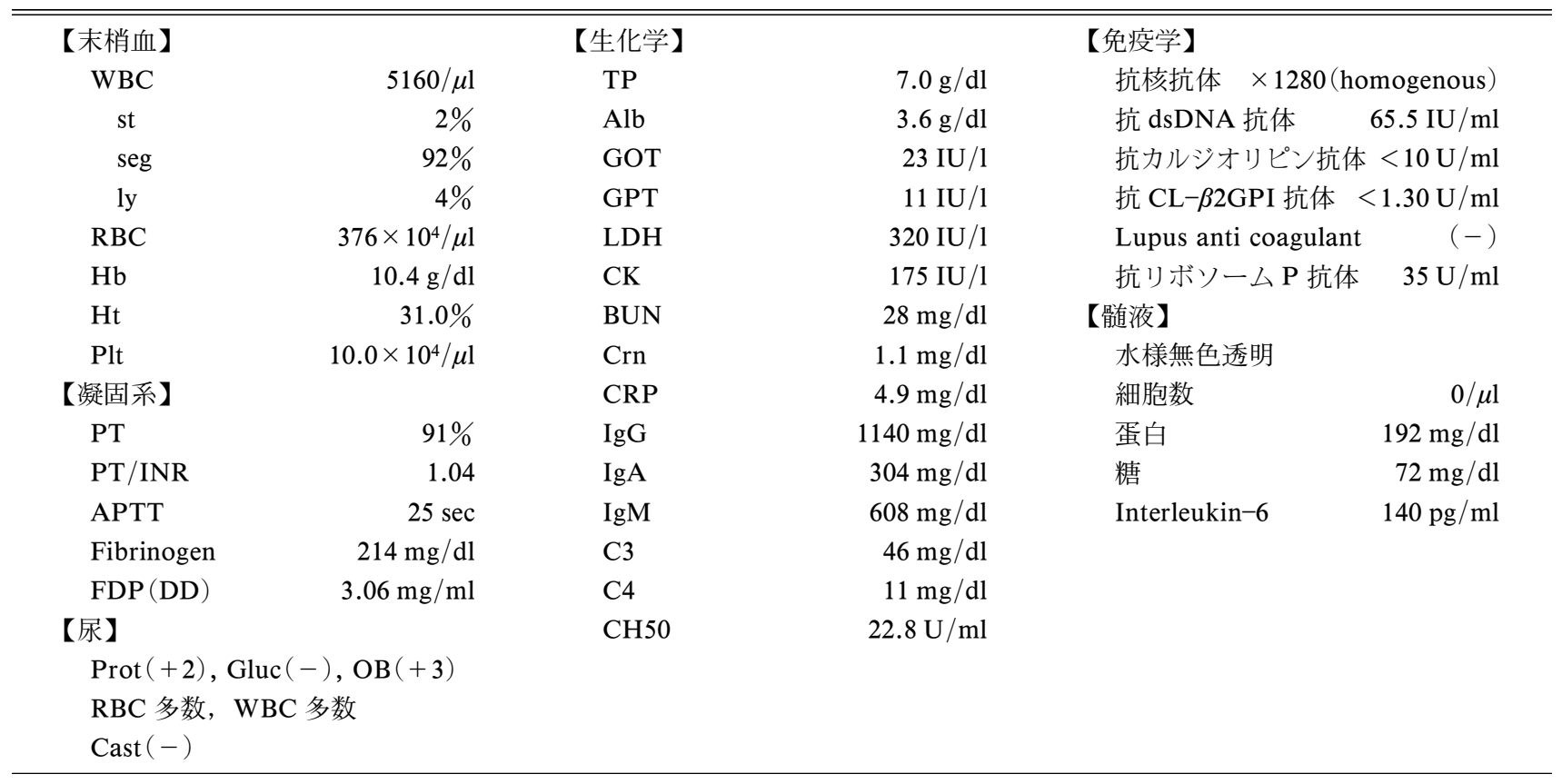




\section{皮膚潰瘍}

膀胱障害、下肢運動·感覚障害

精神症状、痤攣 抗リボソームP抗体 $(\mathrm{U} / \mathrm{ml}) \quad 3537$

Cyclophosphamide pulse $(750 \mathrm{mg} /$ 回) mPSL pulse (1g/日 $\times 3$ 日)

mPSL p.o (mg/日).

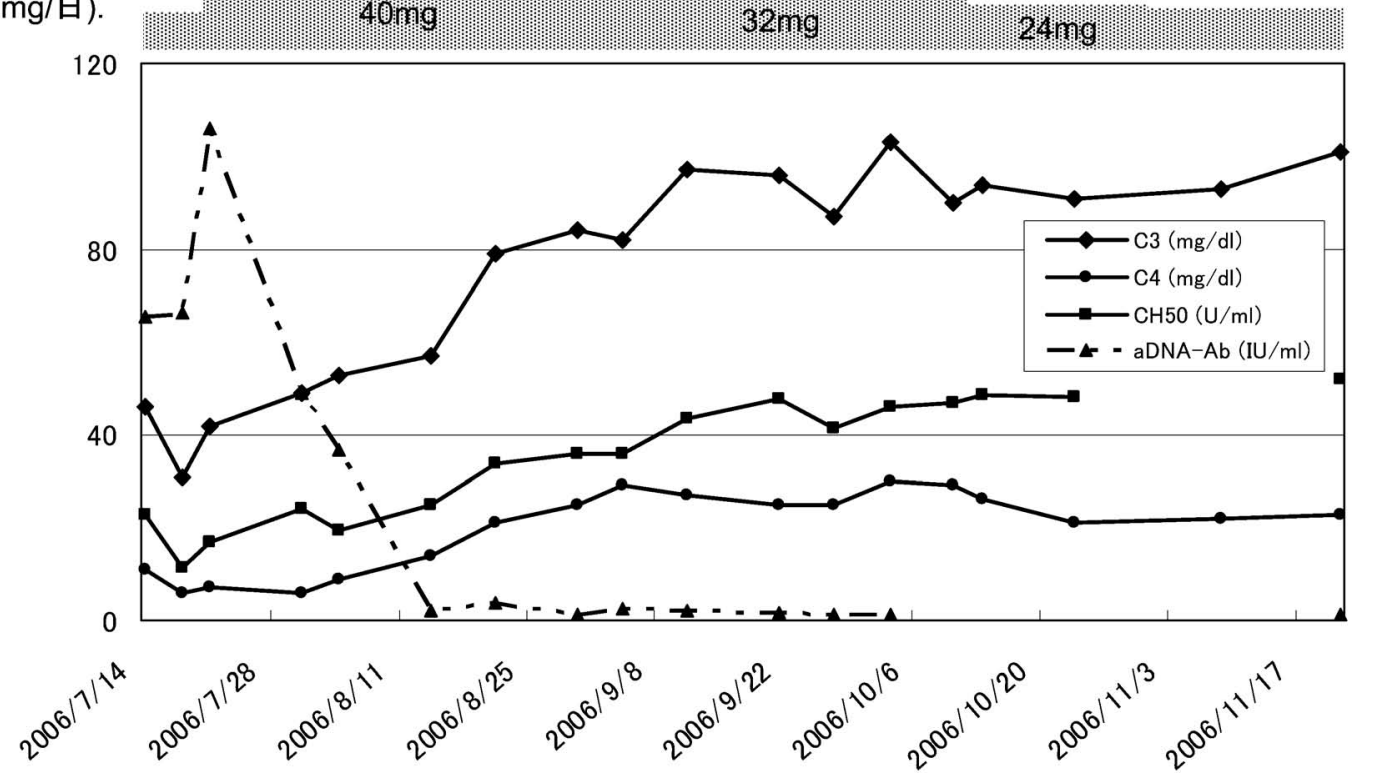

図 1 経過

脂質抗体は，抗カルジオリピン抗体，抗 $\beta 2 \mathrm{GPI}$ 抗 体はいずれも陰性，血清中抗リボソーム $\mathrm{P}$ 抗体は， $35 \mathrm{U} / \mathrm{ml}$ と上昇を認めた。髄液では, 細胞増多はな く, 蛋白 $192 \mathrm{mg} / \mathrm{dl}, \mathrm{IL}-6140 \mathrm{pg} / \mathrm{ml}$ と増加を認め た。頭部 MRI では，脳に明らかな病変を指摘でき なかった（図 2). 春髄 MRI では，胸髄の萎縮所見 が認められたが， cord 内の信号強度の異常や cord の肥厚像は認められなかった（図 3,4$)$.

入院経過（図 1)：入院後, 尿路感染, 腎跙腎炎 に対し，抗生物質と補液により加療を行い，発熱抒 よび食欲不振の改善を認めた。この後, 白血球数 $1960 / \mu \mathrm{l}$, 赤血球数 307 万 $/ \mu \mathrm{l}$, ヘモグロビン值 8.0 $\mathrm{g} / \mathrm{dl}$, 血小板数 5.4 万 $/ \mu \mathrm{l}$ と汎血球減少を認めた. 7 月 24 日, 突然に意識障害を伴う全身性の強直間代 痤攣を生じた。頭部 CT, MRI 上, 脳出血, 脳梗 塞, 脳腫瘍が否定的で, 髄液での蛋白, IL-6 上昇 や血中抗リボソーム $\mathrm{P}$ 抗体上昇から, 中枢神経性 ループスの増悪と判断し，ステロイドパルス療法 (methylprednisolone $1 \mathrm{~g} \times 3$ 日間）を施行し，後療 法として prednisolone $40 \mathrm{mg} /$ 日を内服投与した。

これらにより速やかに意識障害の改善と痤攣の消失

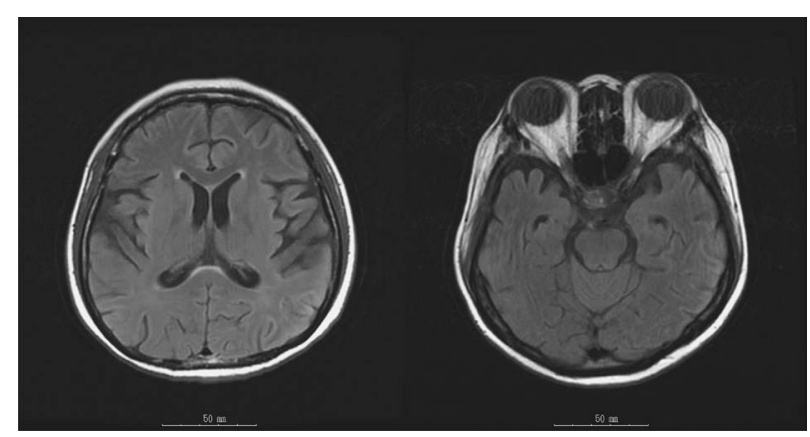

図 2 頭部 MRI（Flare 像） 中枢神経性ループスの明らかな病変は認められない

を認めた。しかしながら同時期より尿閉と便失禁， 下肢の強いしびれが出現した. 膀胱直腸障害と下肢 の運動, 感覚障害, 脊髄 MRI での胸髄萎縮の所見 から，横断性脊髄炎による症状と考えられた． ステ ロイドパルス療法を計 3 クール施行したが症状は増 悪傾向を示し，低補体血症，抗 ds-DNA 抗体価の 高值も持続したため, 中枢神経性ループスに対する さらに強力な治療を導入することとし, cyclophosphamideパルス療法を開始, 月毎に継続した。 1 回 


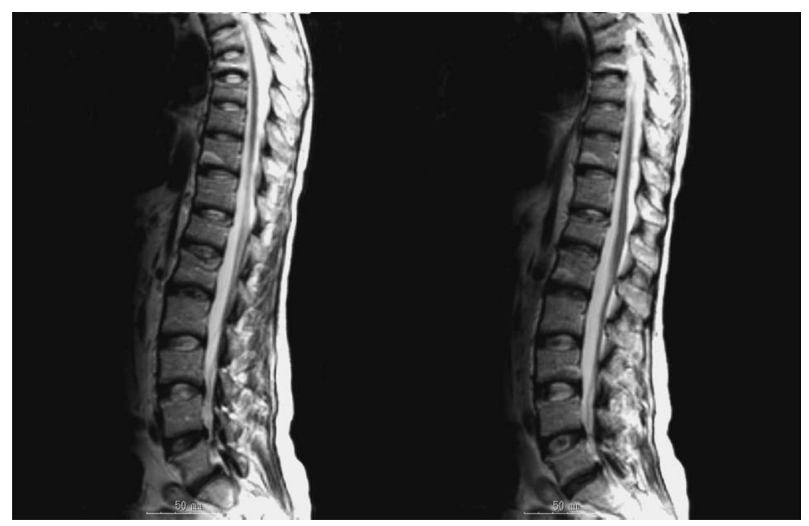

図 3 春髄 MRI（T2WI，矢状断）

胸髄の萎縮を認めるが明らかな肥厚性病変や信号強度の異 常は認められない

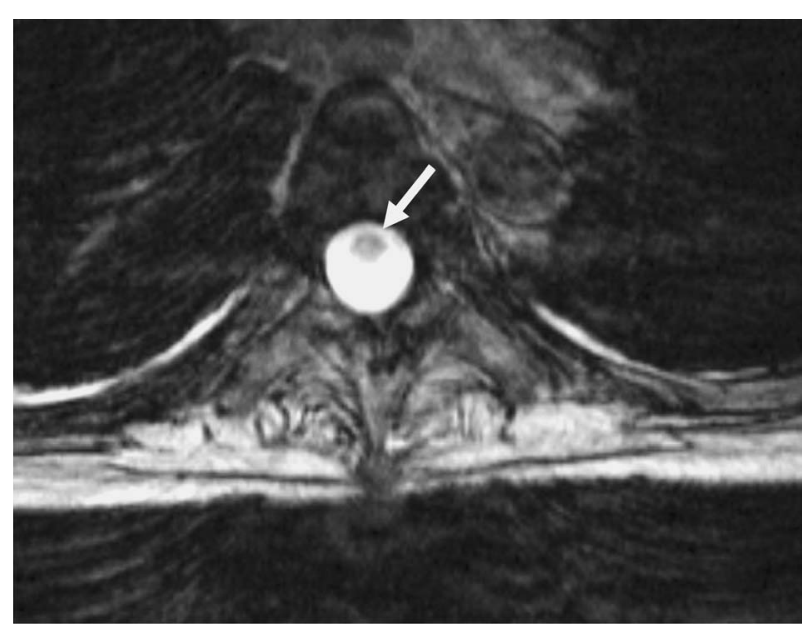

図 4 脊髄 MRI（T2WI，冠状断）

胸髄の萎縮を認める

目の cyclophosphamide 投与後には症状および検査 值の改善は明らかではなかったが，2 回目の投与後 から下肢のしびれ，脱力の改善傾向が明らかとな り, 血清補体価の上昇, 抗 ds-DNA 抗体価の低下

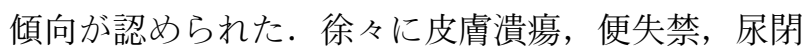
も改善し, 導尿が不要となった。11月には自立歩 行可能, 皮膚潰瘍の治癒, 血清補体価打よび抗 dsDNA 抗体の正常化, 抗リボソーム P 抗体の陰性化 を認め, 退院となった。

\section{考察}

横断性脊髄炎は，中枢神経性ループスにおいて， 1〜2\%に見られる比較的稀な病態であり，20\%程度 の症例に抢いて治療抵抗性を示し, 膀胱直腸障害や 四肢の運動障害，感覚障害が残存しうる ${ }^{1)}$.これま でにもループス春髄炎に対し, cyclophosphamide パルス療法が奏功したとする報告が見られる
が2 5), 本症例においてもループス脊髄炎による膀 胱直腸障害, 運動障害, 感覚障害は, 後遺症を残さ ない程度まで改善した。横断性脊髄炎では, MRI 上 T2 強調像で cord 内の高信号域の出現や cord の 浮腫を反映すると思われる肥厚像を認めることが多 いとされる6,7).この病態に抗リン脂質抗体の関与 を指摘する報告も見られるが8 10), 本症例では抗リ ン脂質抗体は陰性であった. ステロイドパルス療法 と cyclophosphamide パルス療法により症状は著明 に改善し, 血清補体価の上昇や抗 ds-DNA 抗体価 の低下, 血中抗リボソーム $\mathrm{P}$ 抗体価の低下を認め た. 血中抗リボソーム P 抗体は, CNS ループスに おける psychosis や depressionなどの精神症状と関 連することが報告されており11)，また CNS ループ 又の疾患活動性と平行し出現し病因的意義も示唆さ れている12). 本症例に拈いては, 抗体価の推移が中 枢神経性病変, 横断性脊髄炎の改善を反映したもの と思われた。

しかしながら入院前から認められていた下肢筋力 の低下や軽度の排尿障害については, 当初, 両下腿 の難治性皮膚潰瘍による下肢筋の廃用性萎縮やルー プス膀胱炎が関与するものと考えていたが，意識障 害や痙攣, 下肢の感覚障害の明らかでない段階では あったものの, 既に横断性脊髄炎の発症を見たもの と思われ, 今後, 同様の症例に対する診断において 注意すべき点と考えられた.

これまでのところ，ループス脊髄炎に対してはス テロイドおよび cyclophosphamide パルスの併用療 法が有効であったとする報告が多い，本症例におい ても cyclophosphamide のパルス療法で加療後, 膀 胱直腸障害, 下肢の運動障害, 感覚障害が改善して おり, ループス脊髄炎では早期の cyclophosphamide パルス療法の導入を考慮すべきと考えられ た. 最近, 抗 CD20 抗体 (Rituximab) が cyclophosphamide 治療抵抗性のループス脊髄炎による 四肢筋力低下, 感覚障害に即効性をもって奏功した とする報告も見られ13), cyclophosphamideパルス 療法の奏功例も含め, $\mathrm{B}$ 細胞機能の抑制が病態の改 善に関与している可能性が示唆される.

今回, 我々は中枢神経性ループスによる痤攣と ループス精神病, 横断性脊髄炎による膀胱直腸障害 と下肢運動障害, 感覚障害をきたした一例を経験し た、ステロイド剤のみでは治療抵抗性とされている 病態の治療において, ステロイドパルス療法と cyclophosphamide パルス療法が著効し, 中枢神経病 
変改善のマーカーとして, 抗リボソーム $\mathrm{P}$ 抗体価

の推移が有用であったと考えられた。

\section{文献}

1) Kovacs, B., et al. : Transverse myelopathy in systemic lupus erythematosus : an analysis of 14 cases and review of the literature. Ann. Rheum. Dis. 59 : 120-124, 2000.

2) Tokunaga, M., et al. : Successful treatment of intravenous cyclophosphamide pulse therapy for lupus myelitis with urinary disturbance and acute confusional state. Nihon Rinsho Meneki Gakkai Kaishi. 27 : 338-344, 2004.

3) Barile, L., et al. : Transverse myelitis in systemic lupus erythematosus- the effect of IV pulse methylprednisolone and cyclophosphamide. $J$. Rheumatol. 19 : 370-372, 1992.

4) Berlanga, B., et al. : Response to intravenous cyclophosphamide treatment in lupus myelopathy. J. Rheumatol. 19 : 829-830, 1992.

5) Barrile, L., et al. : Controlled clinical trial of IV cyclophosphamide versus IV methylprednisolone in severe neurological manifestations in systemic lupus erythematosus. Ann. Rheum. Dis. 64 : 620-625, 2005.

6) Boumpas, DT., et al. : Acute transverse myelitis in systemic lupus erythematosus : magnetic resonance imaging and review of the literature.
J. Rheumatol. 17 : 89-92, 1990.

7) Provenzale, JM., et al. : Lupus-related myelitis : serial MR findings. Am. J. Neuroradiol. 15 : 1911-1917, 1994.

8) Lavalle, C, et al. : Transverse myelitis: a manifestation of systemic lupus erythematosus strongly associated with antiphospholipid antibodies. J. Rheumatol. 17 : 34-37, 1990.

9) Schantz, V., et al. : Shrinking spinal cord following transverse myelopathy in a patient with systemic lupus erythematosus and the phospholipids antibody syndrome. J. Rheumatol. 25 : 1425-1428, 1998.

10) Smyth, AE., et al. : Transverse myelitis : a complication of systemic lupus erythematosus that is associated with the antiphospholipid syndrome. Ulster. Med. J. 65 : 91-94, 1996.

11) Eber, T., et al. : Anti-ribosomal P-protein and its role in psychiatric manifestations of systemic lupus erythematosus : myth or reality? Lupus. $14:$ 571-575, 2005.

12) A, Hirohata. : Central nervous system involvement in connective tissue disease. Nihon Rinsho Meneki Gakkai Kaishi. 27 : 109-117, 2004.

13) Armstrong, DJ., et al. : SLE-associated transverse myelitis successfully treated with Rituximab (anti-CD20 monoclonal antibody). Rheumatol. Int. 26 : 771-772, 2006. 